\title{
Embryo survival and conceptus growth after reciprocal embryo transfer between Chinese Meishan and Landrace $\times$ Large White gilts
}

\author{
C. J. Ashworth, C. S. Haley*, R. P. Aitken and I. Wilmut* \\ Rowett Research Institute, Bucksburn, Aberdeen AB2 9SB, UK; and *AFRC Institute of Animal \\ Physiology and Genetics Research, Roslin, Midlothian EH25 9PS, UK
}

\begin{abstract}
Summary. Embryos were transferred between Meishan and Landrace $\times$ Large White (control) gilts on Day 4 or 5 to establish approximately equal numbers of all four possible combinations of donor breed and recipient breed. The breed of the donor gilt significantly $(P<0.01)$ affected embryo survival with $44.5 \%$ of transferred Meishan embryos and $69 \cdot 6 \%$ of transferred control embryos surviving to Day $30 \pm 1$. There was no influence of the breed of the recipient gilt on the proportion of embryos which survived. These differences in embryo survival between the two breeds could not be explained by differences in (1) the number of embryos transferred, (2) the stage of development of the embryos transferred, (3) the interval between ovulation and transfer or (4) the degree of asynchrony between donor and recipient gilt.

On Day $30 \pm 1$ embryos from control donors developed into longer fetuses $(P<0.01)$ with larger allantoic sacs $(P<0.05)$ than did embryos from Meishan donors. Fetuses in control recipients were longer $(P<0.01)$, heavier $(P<0.001)$ and had larger allantoic sacs $(P<0.05)$ than fetuses occupying Meishan uteri. The interaction between breed of donor gilt and breed of recipient gilt did not significantly affect conceptus growth.

These results suggest that Meishan pig embryos may be less tolerant to routine embryo transfer procedures than those of control gilts, that the genotype of the dam does not affect the proportion of embryos surviving to Day $30 \pm 1$, and that both fetal and maternal factors affect conceptus growth.
\end{abstract}

Key'rords: Meishan pig; embryo transfer; embryo survival; conceptus growth

\section{Introduction}

Chinese Meishan pigs are noted for their exceptional proliticacy (Yun, 1988) with average litter sizes 30-40\% higher than contemporary Large White pigs (Bolet et al., 1986; Haley \& Lee, 1990). Cross-breeding trials have revealed that the genes controlling prolificacy in Meishans are expressed in the dam (Haley \& Lee, 1990). These authors obtained no evidence to suggest that conceptus genes contribute to the difference in litter size between the breeds.

Ovulation rate imposes the upper limit to litter size in pigs; however, several workers have failed to find evidence of a higher ovulation rate among Meishan females compared with Large White females (Bolet et al., 1986; Bazer et al., 1988a, b; Ellendorff et al., 1988). Comparison of Meishan and Large White females of similar physical age, however, does indicate that Meishan sows shed more eggs (Haley \& Lee, 1990). The main reason for Meishan prolificacy appears to be an increased prenatal survival (Bidanel \& Legault, 1986; Bazer et al., 1988b; Haley et al., 1990) due either to a uterine environment which is capable of supporting the growth and development of many embryos, or to an improved quality or viability of embryos produced. In the present experiment reciprocal 
embryo transfer was used to determine which of these alternatives primarily promotes prolificacy in Meishan pigs, and to assess the contribution of fetal and maternal factors to the growth and development of the feto-placental unit. A preliminary report of this experiment has been presented elsewhere (Ashworth et al., 1989).

\section{Materials and Methods}

\section{Animals and techniques}

Experimental animals. Forty Meishan gilts and 6 Meishan boars obtained from the Edinburgh Station of the Institute of Animal Physiology and Genetics Research, together with 40 contemporary Landrace $\times$ Large White (control) gilts and 4 Large White boars from the Rowett Research Institute herd were used in this experiment. All gilts were checked daily for oestrous behaviour in the presence of an intact boar from approximately 2 (Meishan gilts) or 4 (control gilts) months of age until 7-8 months of age when treatment was begun for oestrous synchronization. At this age, Meishan gilts had experienced 4 or 5 oestrous cycles, whereas control gilts had experienced 2 or 3 oestrous cycles. The mean ages at puberty of Meishan and control gilts were 114.7 \pm 2.7 days and 179.2 \pm 2.5 days respectively. All gilts were penned individually and fed $20 \mathrm{mg}$ allyltrenbolone (Regumate: Hoechst, Hounslow, Middlesex, UK) daily for 18 days. Gilt weights were recorded on the day before the start of feeding with allyltrenbolone. After withdrawal of allyltrenbolone, gilts were checked twice daily for signs of oestrus, at $08: 00 \mathrm{~h}$ and $16: 00 \mathrm{~h}$ in the presence of an intact mature boar. At oestrus, gilts were assigned to be embryo donors or embryo recipients to achieve approximately equal numbers of all four possible combinations of donor breed and recipient breed. At $0 \mathrm{~h}$ and $12 \mathrm{~h}$ after the observed onset of oestrus, gilts assigned to be embryo donors were naturally mated by two different boars, each of the same breed as the gilt, ensuring that matings between siblings and half-siblings were avoided.

Embryo transfer. Embryos were transferred between Day 4 control gilts and Day 5 Meishan gilts (Day 0 is day of onset of oestrus) to correct for the longer interval between oestrus and ovulation in Meishan females (Wilmut $e t$ al., 1990) and therefore obtain embryos from both breeds at comparable post-ovulatory ages and stages of development.

Embryos were recovered from the anterior $20 \mathrm{~cm}$ of each uterine horn using established surgical procedures (Polge, 1982). Upon recovery from the uterus embryos were classified according to their developmental stage as described by Wilmut et al. (1990), held in ovum culture medium (Flow Laboratories, Irvine, UK) at $37^{\circ} \mathrm{C}$ and transferred to unmated recipient gilts within $2 \mathrm{~h}$. All embryos from a single donor were transferred to a single recipient. The numbers of corpora lutea on each ovary were counted at the time of surgery.

Embryo survival and fetal growth. Recipient gilts were checked for oestrous behaviour daily using an intact boar. Recipient gilts which had not returned to oestrus by Day $30 \pm 1$ were slaughtered and the reproductive tract recovered. Ovaries and uteri were dissected for counts of numbers of corpora lutea and fetuses, respectively. The position of each feto-placental unit within the uterus, the volume of each allantoic sac and the crown-rump length and weight of each fetus was recorded.

\section{Data analyses}

Characteristics of transfers. Breed differences in ovulation rate, in the interval between the final allyitrenbolone feed and oestrus and in gilt weight were analysed by linear models as implemented in the GLIM statistical package (Baker \& Nelder, 1978) with a normal error. These comparisons were made between all gilts (donors and recipients) undergoing transfers. The effect of breed of donor, breed of recipient and the donor breed $x$ recipient breed interaction were tested on a further four explanatory variables; the mean stage of embryos transferred, the number of embryos transferred, the interval in hours between estimated ovulation and transfer, and the degree of asynchrony between donor and recipient gilt. Embryos were classified (from ' 5 ' for a 2-celled embryo to ' 11 ' for an early blastocyst; Wilmut et al., 1990) according to their stage of development at the time of transfer. Analyses of embryo mean stage were performed using GLIM with a normal error. The timing of ovulation and interval between estimated ovulation and transfer were estimated by assuming that oestrus occurred midway between the time when oestrus was first detected and the previous occasion when oestrous activity was monitored. Ovulation was assumed to have occurred 34.3 or $49 \mathrm{~h}$ after oestrus in control gilts or Meishan gilts respectively (Wilmut et al., 1990; F. MartinatBotte, F. W. Bazer \& M. Terqui, unpublished data). The degree of asynchrony was defined as the estimated time in hours between ovulation in the donor gilt and ovulation in the recipient gilt.

Outcome of pregnancy. Recipients in which pregnancy was maintained (scored as '1') were compared with those which returned to oestrus before Day 30 (scored as ' 0 ') using GLIM with a binomial error and gamma link. Effects included in the model were the breed of donor, breed of recipient, weight, interval between withdrawal of allyltrenbolone and oestrus, ovulation rate, mean stage of transferred embryos, the number of transferred embryos, the interval between ovulation and transfer and the degree of asynchrony.

The following analyses were performed on recipients which were pregnant at the time of slaughter, using the GENSTAT statistical package (GENSTAT 5 Committee, 1989) with a normal error. The numbers and proportions 
of transferred embryos which survived were considered in three categories: Tl, embryos which survived to be represented by viable fetuses, moribund fetuses or dead fetuses (represented by fragmenting fetuses or resorbing fetal membranes) on Day $30 \pm 1$; T2, embryos represented by moribund or dead fetuses on Day $30 \pm 1$; and T3, embryos represented by viable fetuses on Day $30 \pm 1$ (i.e. $\mathrm{T} 1=\mathrm{T} 2+\mathrm{T} 3$ ). Analyses of the proportion of transferred embryos which survived were carried out after transformation of the proportions to angles (Snedecor \& Cochran, 1967). In these analyses the effects tested were the breed of donor, the breed of recipient and their interaction, and the regressions on mean embryo stage, the interval between ovulation and transfer and the degree of asynchrony allowing the regressions to differ between recipient breeds. In analyses of proportions of embryos surviving, the effect of the numbers of embryos transferred was also examined.

Measures of conceptus growth. Analyses of surviving conceptus length, weight and allantoic fluid volume were performed using GENSTAT. In these analyses factors measuring variation between gilts, such as breed effects or embryo mean stage, were tested against variation between gilts within transfer groups. Within gilts, the position of a fetus within the uterine horn and the number of adjacent moribund fetuses $(0,1$ or 2$)$ were tested against variation within females. To express fetal position within a uterine horn on a uniform scale, irrespective of the number of fetuses in that horn, the location of the fetus was expressed as a proportion along the length of the horn from the tip (0) to the bifurcation (1). The fetus closest to the ovary would therefore be at position $1 / 2 \mathrm{n}$, and its nearest neighbour at position $3 / 2 \mathrm{n}$, where $\mathrm{n}$ is the number of fetuses in the horn. The variables included in the model were breed of donor, breed of recipient and their interaction. The covariates of mean stage of embryos transferred, day of slaughter, number of fetuses in the same horn, position, and the number of adjacent moribund fetuses were included in the analyses.

\section{Results}

\section{Characteristics of transfers}

Thirty-two embryo transfers were performed. The remaining 16 gilts did not exhibit oestrus at the expected time or were without a suitable partner to form a transfer pair. Breed differences in ovulation rate, the interval between allyltrenbolone withdrawal and oestrus and gilt weight are shown in Table 1. The interval between the final feed of allyltrenbolone and oestrus was not significantly correlated with gilt weight.

Table 1. Overall breed differences

\begin{tabular}{lccc}
\hline & Meishan & Control & Significance \\
\hline No* $^{*}$ & 30 & 32 & \\
$\begin{array}{l}\text { Ovulation rate } \\
\text { Interval from withdrawal of } \\
\text { allyltrenbolone to oestrus (days) }\end{array}$ & $21.67 \pm 0.63$ & $17.10 \pm 0.88$ & $P<0.01$ \\
$\begin{array}{l}\text { Weight }(\mathrm{kg}) \text { immediately before } \\
\text { treatment with allyltrenbolone }\end{array}$ & $5.93 \pm 0.23$ & $6.88 \pm 0.32$ & $P<0.05$ \\
\hline
\end{tabular}

Values are means \pm s.e.m.

*Data from 2 Meishan gilts are missing because values on the interval from allyltrenbolone withdrawal to oestrus were not available.

†Ovulation rates were estimated during surgery in donor gilts and recipient gilts which returned to oestrus before Day 30 , and by counting corpora lutea by ovarian dissection following slaughter of pregnant recipient gilts.

The characteristics of the embryos transferred in each of the four transfer groups are shown in Table 2. There were no significant differences in mean stage of embryos transferred, degree of asynchrony or the interval between ovulation and transfer between the four groups. The mean stage of development of embryos recovered from individual gilts and the variation in embryo developmental stage within gilts is presented elsewhere (Haley et al., 1990). Larger numbers of Meishan embryos were transferred than control embryos (Table 2), reflective of the higher ovulation rate observed in Meishan gilts. 
Table 2. Characteristics of embryos transferred

\begin{tabular}{|c|c|c|c|c|c|c|}
\hline \multirow[b]{2}{*}{ Breed of recipient } & \multicolumn{2}{|c|}{ Meishan donor } & \multicolumn{2}{|c|}{ Control donor } & \multirow{2}{*}{\multicolumn{2}{|c|}{$\begin{array}{l}\text { Significance } \\
\text { of breed effects }\end{array}$}} \\
\hline & Meishan & Control & Meishan & Control & & \\
\hline No. & 9 & 6 & 8 & 9 & & \\
\hline $\begin{array}{l}\text { Mean stage of embryos } \\
\text { transferred } \dagger\end{array}$ & $\begin{array}{l}8 \cdot 17 \\
\pm 0 \cdot 534\end{array}$ & $\begin{aligned} & 9 \cdot 84 \\
\pm & 0 \cdot 706\end{aligned}$ & 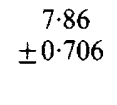 & $\begin{array}{c}8 \cdot 13 \\
\pm 0.632\end{array}$ & $\begin{array}{l}\text { Donor } \\
\text { Recipient } \\
\text { Donor } \times \text { Recipient }\end{array}$ & $\begin{array}{l}\text { ns } \\
\text { ns } \\
\text { ns }\end{array}$ \\
\hline $\begin{array}{l}\text { No. of embryos } \\
\text { transferred to each } \\
\text { recipient }\end{array}$ & $\begin{array}{l}21 \cdot 0 \\
\pm 1 \cdot 26\end{array}$ & $\begin{array}{l}26 \cdot 5 \\
\pm 1 \cdot 66\end{array}$ & $\begin{array}{r}18 \cdot 25 \\
\pm 1 \cdot 66\end{array}$ & $\begin{array}{l}15 \cdot 3 \\
\pm 1 \cdot 49\end{array}$ & $\begin{array}{l}\text { Donor } \\
\text { Recipient } \\
\text { Donor } \times \text { Recipient }\end{array}$ & $\begin{array}{l}P<0.001 \\
\text { ns } \\
P<0.05\end{array}$ \\
\hline $\begin{array}{l}\text { Interval from ovulation } \\
\text { to transfer }(\mathrm{h})\end{array}$ & $\begin{array}{r}71 \cdot 8 \\
\pm 3 \cdot 0\end{array}$ & $\begin{array}{r}66 \cdot 7 \\
\pm 3 \cdot 7\end{array}$ & $\begin{array}{r}73 \cdot 9 \\
+3 \cdot 2 \\
\end{array}$ & $\begin{array}{r}70 \cdot 1 \\
\pm 3 \cdot 0\end{array}$ & $\begin{array}{l}\text { Donor } \\
\text { Recipient } \\
\text { Donor } \times \text { Recipient }\end{array}$ & $\begin{array}{l}\text { ns } \\
\text { ns } \\
\text { ns }\end{array}$ \\
\hline $\begin{array}{l}\text { Degree of asynchrony } \\
\text { between donor and } \\
\text { recipient }(\mathrm{h})\end{array}$ & $\begin{array}{l}-2 \cdot 67 \\
\pm 4 \cdot 13\end{array}$ & $\begin{array}{l}-3 \cdot 3 \\
\pm 5 \cdot 06\end{array}$ & $\begin{array}{r}7 \cdot 46 \\
\pm 4 \cdot 39\end{array}$ & $\begin{array}{l}-1 \cdot 33 \\
\pm 4 \cdot 13\end{array}$ & $\begin{array}{l}\text { Donor } \\
\text { Recipient } \\
\text { Donor } \times \text { Recipient }\end{array}$ & $\begin{array}{l}\text { ns } \\
\text { ns } \\
\text { ns }\end{array}$ \\
\hline
\end{tabular}

Values are means \pm s.e.m.

$\nmid$ Embryos were classified from ' 5 ' for a 2-celled embryo to ' 11 ' for an early blastocyst.

\section{Outcome of pregnancy}

Twelve recipient gilts returned to oestrus before Day 30. There were no significant differences between the four transfer groups in the numbers of recipient gilts which returned to oestrus, with $66.7 \%$ and $55.6 \%$ of control gilts receiving Meishan or control embryos respectively, remaining pregnant and $77.8 \%$ and $50 \%$ of Meishan gilts receiving Meishan or control embryos respectively, remaining pregnant. Both Meishan and control recipient gilts which remained pregnant had more corpora lutea $(24.0 \pm 1.00$ and $18.33 \pm 0.816$, respectively) than did recipients which returned to oestrus $(19.0 \pm 1.033$ and $16.17 \pm 1.195$ corpora lutea, respectively $(P<0.05)$. There were no significant differences between the four transfer groups in the total number of fetuses or the number of viable fetuses on Day $30 \pm 1$ (Table 3).

Table 3. Numbers of transferred embryos which survived

\begin{tabular}{|c|c|c|c|c|c|c|}
\hline \multirow[b]{2}{*}{ Breed of recipient } & \multicolumn{2}{|c|}{ Meishan donor } & \multicolumn{2}{|c|}{ Control donor } & \multirow{2}{*}{\multicolumn{2}{|c|}{$\begin{array}{c}\text { Significance } \\
\text { of breed effects }\end{array}$}} \\
\hline & Meishan & Control & Meishan & Control & & \\
\hline $\begin{array}{l}\text { Total no. of fetuses and } \\
\text { resorbing fetal } \\
\text { membranes on Day } \\
30 \pm 1 \text { (T1) }\end{array}$ & $\begin{array}{r}11.43 \\
\pm 1.81\end{array}$ & $\begin{array}{l}18 \cdot 75 \\
\pm 2 \cdot 4\end{array}$ & $\begin{array}{l}13 \cdot 25 \\
\pm 2 \cdot 4\end{array}$ & $\begin{array}{l}11 \cdot 8 \\
\pm 2 \cdot 15\end{array}$ & $\begin{array}{l}\text { Donor } \\
\text { Recipient } \\
\text { Donor } \times \text { Recipient }\end{array}$ & $\begin{array}{l}\mathrm{ns} \\
\mathrm{ns} \\
\mathrm{ns}\end{array}$ \\
\hline $\begin{array}{l}\text { No. of moribund fetuses } \\
\text { and resorbing fetal } \\
\text { membranes on Day } \\
30 \pm 1 \text { (T2) }\end{array}$ & $\begin{array}{r}2 \cdot 14 \\
\pm 1 \cdot 09\end{array}$ & $\begin{array}{r}6.75 \\
\pm 1.44\end{array}$ & $\begin{aligned} & 0.5 \\
\pm & 1.44\end{aligned}$ & $\begin{array}{r}0 \cdot 8 \\
\pm 1 \cdot 29\end{array}$ & $\begin{array}{l}\text { Donor } \\
\text { Recipient } \\
\text { Donor } \times \text { Recipient }\end{array}$ & $\begin{array}{l}P<0.05 \\
\text { ns } \\
\text { ns }\end{array}$ \\
\hline $\begin{array}{l}\text { No. of viable fetuses on } \\
\text { Day } 30 \pm 1 \text { (T3) }\end{array}$ & $\begin{array}{r}9.29 \\
\pm 1.57\end{array}$ & $\begin{array}{l}12 \cdot 0 \\
\pm 2 \cdot 08\end{array}$ & $\begin{array}{r}12 \cdot 75 \\
\pm 2 \cdot 08\end{array}$ & $\begin{array}{l}11 \cdot 0 \\
\pm 1 \cdot 86\end{array}$ & $\begin{array}{l}\text { Donor } \\
\text { Recipient } \\
\text { Donor } \times \text { Recipient }\end{array}$ & $\begin{array}{l}\text { ns } \\
\text { ns } \\
\text { ns }\end{array}$ \\
\hline
\end{tabular}

Values are means \pm s.e.m. 
The proportions of embryos surviving in each of the three stages of pregnancy investigated (T1, T2 and T3) are shown in Table 4. There was a significant effect of breed of donor on the angular transformed proportions of embryos surviving in each of the three categories, but no effect of recipient breed or the interaction between breed of donor and recipient. The number of embryos transferred did not affect the proportion which survived. Both the mean stage of transferred embryos and the estimated interval between ovulation and transfer significantly affected the proportion of embryos which survived in T1, T2 and T3 and these effects differed between recipient breeds. The predicted mean percentages of embryos surviving in each group after fitting these effects and back-transforming from the angular scale are shown in Table 4 . These means were predicted from the approximate mean stage of embryos transferred, the mean time, in hours, between donor ovulation and transfer and with no asynchrony between donor and recipient gilts. As the means predicted after adjustment for the covariates were very similar to the observed means, it can be concluded that the covariates do not explain the differences between the transfer groups at any of the three stages investigated.

Table 4. Percentages of transferred embryos which survived

\begin{tabular}{|c|c|c|c|c|c|c|c|}
\hline \multirow[b]{2}{*}{ Breed of recipient } & & \multicolumn{2}{|c|}{ Meishan donor } & \multicolumn{2}{|c|}{ Control donor } & \multirow{2}{*}{\multicolumn{2}{|c|}{$\begin{array}{c}\text { Significance } \\
\text { of breed effects }\end{array}$}} \\
\hline & & Meishan & Control & Meishan & Control & & \\
\hline No. & & 7 & 4 & 4 & 5 & & \\
\hline $\begin{array}{l}\% \text { of embryos } \\
\text { represented by } \\
\text { fetuses or } \\
\text { resorbing fetal } \\
\text { membranes on } \\
\text { Day } 30 \pm 1 \\
\text { (T1) }\end{array}$ & $\begin{array}{l}\text { Observed } \\
\text { mean } \\
\text { Predicted } \\
\text { mean } \dagger\end{array}$ & $\begin{array}{r}53.6 \\
\pm 6.7 \\
56.6 \\
\pm 4.8\end{array}$ & $\begin{array}{r}69 \cdot 9 \\
\pm 8.9 \\
61 \cdot 5 \\
\pm 5 \cdot 7\end{array}$ & $\begin{array}{r}74 \cdot 2 \\
\pm 8 \cdot 9 \\
76 \cdot 1 \\
\pm 4 \cdot 7\end{array}$ & $\begin{array}{r}73 \cdot 0 \\
\pm 7 \cdot 9 \\
80 \cdot 2 \\
\pm 3 \cdot 5\end{array}$ & $\begin{array}{l}\text { Donor } \\
\text { Recipient } \\
\text { Donor } \times \text { Recipient }\end{array}$ & $\begin{array}{l}P<0.01 \\
\text { ns } \\
\text { ns }\end{array}$ \\
\hline $\begin{array}{l}\% \text { of embryos } \\
\text { in } \mathrm{Tl} \\
\text { represented by } \\
\text { viable fetuses } \\
\text { on Day } 30 \pm 1 \\
\text { (T2) }\end{array}$ & $\begin{array}{l}\text { Observed } \\
\text { mean } \\
\text { Predicted } \\
\text { mean }\end{array}$ & $\begin{array}{r}80 \cdot 7 \\
\pm 5 \cdot 4 \\
80 \cdot 5 \\
\pm 4.9\end{array}$ & $\begin{array}{r}65 \cdot 9 \\
\pm 7 \cdot 1 \\
72 \cdot 1 \\
\pm 6 \cdot 9\end{array}$ & $\begin{array}{r}95 \cdot 8 \\
\pm 7 \cdot 1 \\
96.7 \\
\pm 2.7\end{array}$ & $\begin{array}{r}94.4 \\
\pm 6 \cdot 3 \\
92 \cdot 3 \\
\pm 3.8\end{array}$ & $\begin{array}{l}\text { Donor } \\
\text { Recipient } \\
\text { Donor } \times \text { Recipient }\end{array}$ & $\begin{array}{l}P<0.01 \\
\text { ns } \\
\text { ns }\end{array}$ \\
\hline $\begin{array}{l}\% \text { of embryos } \\
\text { represented by } \\
\text { viable fetuses } \\
\text { on Day } 30 \pm 1 \\
\text { (T3) }\end{array}$ & $\begin{array}{l}\text { Observed } \\
\text { mean } \\
\text { Predicted } \\
\text { mean }\end{array}$ & $\begin{array}{r}43 \cdot 3 \\
\pm 6 \cdot 4 \\
46 \cdot 5 \\
\pm 6 \cdot 0\end{array}$ & $\begin{array}{r}45 \cdot 6 \\
\pm 8 \cdot 4 \\
41 \cdot 2 \\
\pm 7 \cdot 2\end{array}$ & $\begin{array}{r}70 \cdot 8 \\
\pm 8 \cdot 4 \\
75 \cdot 3 \\
\pm 5.9\end{array}$ & $\begin{array}{r}68 \cdot 3 \\
\pm 7 \cdot 5 \\
70 \cdot 5 \\
\pm 4 \cdot 9\end{array}$ & $\begin{array}{l}\text { Donor } \\
\text { Recipient } \\
\text { Donor } \times \text { Recipient }\end{array}$ & $\begin{array}{l}P<0.01 \\
\text { ns } \\
\text { ns }\end{array}$ \\
\hline
\end{tabular}

Values are means \pm s.e.m.

tPredicted means were derived from a statistical model including breed of donor and of recipient and their interaction and regressions on mean stage of transferred embryos, interval between ovulation and transfer and degree of asynchrony.

\section{Measures of conceptus growth}

The observed mean allantoic fluid volume, crown-rump length and weight of viable fetuses in each of the four transfer groups is shown in Table 5. Embryos from control donors developed into longer fetuses $(+1.07 \pm 0.25 \mathrm{~mm}, P<0.01)$ with larger allantoic sacs $(+22.8 \pm 7.4 \mathrm{ml}, P<0.05)$ than did embryos from Meishan donors. Fetuses in control recipients were longer $(+1.29 \pm$ $0.26 \mathrm{~mm}, P<0.01)$, heavier $(+0.222 \pm 0.029 \mathrm{~g}, P<0.001)$ and had larger allantoic sacs $(+36.2 \pm 7.2 \mathrm{ml}, P<0.01)$ than did fetuses occupying Meishan uteri. There were no significant interactions between breed of donor and breed of recipient for these three measurements. The 
regressions on the mean stage of embryos at the time of transfer were positive and significant for fetal crown-rump length $(+0.63 \pm 0.09 \mathrm{~mm}, P<0.001)$ and fetal weight $(+0.074 \pm 0.010 \mathrm{~g}$, $P<0.001)$. Fetuses from recipient gilts with higher total numbers of fetuses had smaller allantoic sacs, and were shorter and lighter, the regressions on a per conceptus basis being $-8 \cdot 00 \pm 1 \cdot 32 \mathrm{ml}$ $(P<0.01),-0.20 \pm 0.04 \mathrm{~mm}(P<0.01)$ and $-0.029 \pm 0.005 \mathrm{~g}(P<0.05)$, respectively. The regressions of allantoic fluid volume $(+25.1 \pm 6.4 \mathrm{ml}, P<0.01)$, crown-rump length $(+165 \pm$ $0.21 \mathrm{~mm}, P<0.001)$ and fetal weight $(+0.272 \pm 0.023 \mathrm{~g}, P<0.001)$ on day of pregnancy were significant and positive. Allantoic fluid volume increased towards the tip of the uterine horn, the regression on position being $-26.9 \pm 12 \cdot 1 \mathrm{ml}(P<0.05)$.

Table 5. Measures of conceptus growth on Day $30 \pm 1$ of pregnancy

\begin{tabular}{|c|c|c|c|c|c|}
\hline \multirow[b]{2}{*}{ Breed of recipient } & & \multicolumn{2}{|c|}{ Meishan donor } & \multirow{2}{*}{$\frac{\text { Control donor }}{\text { Meishan }}$} & \multirow[b]{2}{*}{ Control } \\
\hline & & Meishan & Control & & \\
\hline No. & & 7 & 4 & 4 & 5 \\
\hline $\begin{array}{l}\text { Allantoic fluid } \\
\text { volume }(\mathrm{ml})\end{array}$ & $\begin{array}{l}\text { Observed mean } \\
\text { Predicted mean }\end{array}$ & $\begin{array}{l}109.4 \pm 6.7 \\
116.2 \pm 6.8\end{array}$ & $\begin{array}{l}113.5 \pm 7.8 \\
125.3 \pm 9.4\end{array}$ & $\begin{array}{l}130 \cdot 5 \pm 7 \cdot 5 \\
128.8 \pm 7 \cdot 5\end{array}$ & $\begin{array}{l}174 \cdot 4 \pm 7 \cdot 3 \\
171 \cdot 0 \pm 7 \cdot 0\end{array}$ \\
\hline $\begin{array}{l}\text { Crown-rump length } \\
(\mathrm{mm})\end{array}$ & $\begin{array}{l}\text { Observed mean } \\
\text { Predicted mean }\end{array}$ & $\begin{array}{r}21 \cdot 6 \pm 0.26 \\
22 \cdot 19 \pm 0.23\end{array}$ & $\begin{array}{l}23.64 \pm 0.3 \\
23.42 \pm 0.31\end{array}$ & $\begin{array}{l}23.45 \pm 0.29 \\
23.22 \pm 0.25\end{array}$ & $\begin{array}{l}24 \cdot 84 \pm 0.28 \\
24.53 \pm 0.23\end{array}$ \\
\hline Fetal weight (g) & $\begin{array}{l}\text { Observed mean } \\
\text { Predicted mean }\end{array}$ & $\begin{array}{l}0.760 \pm 0.032 \\
0.830 \pm 0.026\end{array}$ & $\begin{array}{l}1.062 \pm 0.038 \\
1.029 \pm 0.036\end{array}$ & $\begin{array}{l}0.956 \pm 0.036 \\
0.909 \pm 0.029\end{array}$ & $\begin{array}{l}1 \cdot 166 \pm 0.035 \\
1 \cdot 113 \pm 0.027\end{array}$ \\
\hline
\end{tabular}

Values are means \pm s.e.m.

$\nmid$ Predicted means were derived from a statistical model including breed of donor, and of recipient and their interaction and regressions on mean stage of transferred embryos, number of fetuses in uterine horn, day of pregnancy and position of the feto-placental unit in the uterus.

The effects of the covariates did not explain the observed breed differences in conceptus growth. The predicted means for each of the three traits in each of the four transfer groups are shown in Table 5. These means were predicted in a model including breed of donor and recipient and with covariates having significant effect fixed at their approximate mean values (i.e. 8-5 for mean stage of embryos at transfer, 7 fetuses in each uterine horn, Day 30 of pregnancy and at the mid-point in the uterine horn).

The contribution of recipient breed and donor breed to the three measures of conceptus growth was similar for allantoic fluid volume $(36.2 \pm 11.2 \mathrm{ml}$ and $22.8 \pm 11.5 \mathrm{ml}$, respectively), and fetal length ( $1.29 \pm 0.34$ and $1.07 \pm 0.32$, respectively), but the contribution of recipient breed to the observed differences in fetal weight was approximately $2 \cdot 5$-fold that of the donor breed $(0.202 \pm 0.045$ and $0.081 \pm 0.042$, respectively). Correlations between each of the three measures of conceptus growth investigated were all highly significant $(P<0.001$ in each case $)$.

\section{Discussion}

This experiment has demonstrated that Meishan embryos are less tolerant to routine embryo transfer procedures than are control Landrace $\times$ Large White embryos. Both the proportion of recipient gilts that remained pregnant and the proportion of control embryos which survived following transfer were within the usual range (Polge, 1982), indicating that the embryo transfer procedure per se was satisfactory. The poor survival of Meishan embryos may reflect a reduction in embryo viability before transfer or may indicate that optimal embryo transfer conditions differ between Meishan and control embryos. Optimal conditions for pig embryo transfer have been determined using European breeds of pig. The requirements of Meishan embryos for factors such as incubation media and the degree 
of synchrony between donor and recipient gilt at the time of transfer may differ from control embryos, despite the apparent absence of morphological or developmental differences between embryos from the two breeds. The medium used for embryo incubation was selected following observations indicating that, before the blastocyst stage, pig embryos remain viable in a relatively simple medium (Davis, 1985) and that supplementation of media with vitamins and amino acids was detrimental to viability in vitro (Meyen et al., 1989). However, Meishan embryos may require a more complex nutrient source.

The degree of synchrony between donor and recipient gilts is not believed to be a major factor leading to Meishan embryo death in this experiment. Firstly, in the across-breed transfer groups, embryos were transferred between Meishan gilts on Day 5 after oestrus and control gilts on Day 4. In an experiment in which Day-6 pig embryos were transferred to Day-7 recipient gilts, and Day-7 embryos were transferred to Day-6 recipients, embryo survival was higher in the latter group in which embryos were advanced relative to the recipient (Pope et al., 1986). In the present experiment therefore, it may have been expected that embryo survival would have been higher when Meishan embryos were transferred to control recipients than when control embryos were transferred to Meishan recipients. Secondly, embryo survival was equally low irrespective of whether the Meishan embryos (Day 5) were transferred to Meishan (Day 5) or control (Day 4) recipients. Thirdly, the interval between onset of oestrus and ovulation is about $12 \mathrm{~h}$ longer in Meishan females than in Large White females (Wilmut et al., 1990; F. Martinat-Botte, F. W. Bazer \& M. Terqui, unpublished data). Therefore, the post-ovulatory age of the embryos in the across-breed transfer groups would only differ by about $12-14 \mathrm{~h}$ on average. Indeed, in the current experiment, there were no significant differences in the estimated degree of asynchrony between donor and recipient gilts in the four transfer groups.

The use of means predicted from the model fitted (Table 4) allows the comparison of the transfer groups after adjustment for small differences between groups in the mean value of covariates (e.g. small differences in the mean stage of embryos). The differences between the observed and the predicted means are all small (Table 4). It would therefore appear that none of the covariates inspected (mean stage of embryos transferred, interval between ovulation and transfer and degree of asynchrony) has a major role in explaining the observed differences in survival between transfer groups.

Alternatively, embryo viability may have been compromised before transfer. There are no reports describing the administration of allyltrenbolone to Meishan gilts. This progestagen has, however, been used successfully to synchronize oestrus immediately before mating in peri-pubertal Large White $\times$ Landrace gilts of similar weight to the Meishan gilts used in this study (Varley $e t$ al., 1989); these gilts gave birth to litters of normal size.

In the current study Meishan gilts had, on average, 4.57 more corpora lutea than did control gilts. Haley \& Lee (1990) also noted a breed difference in ovulation rate in favour of Meishan, with Meishan gilts and sows having 4 and 5.5 more corpora lutea than Large White gilts and sows, respectively. The reason for the apparent discrepancy between these observations and accounts of lower ovulation rates in Meishan females (Bazer et al., 1988a, b; Ellendorff et al., 1988) remains to be elucidated. It is not clear whether these authors compared Large White and Meishan females of a similar age, or females which had experienced a similar number of post-pubertal oestrous cycles. Bolet et al. (1986) observed that ovulation rate in Meishan gilts increases significantly between the first and third oestrus, whereas there was no comparable increase in Large White gilts. This may indicate that Meishan gilts only reach a mature ovulation rate after several oestrous cycles. Alternatively, as the animals used in the current study, and those described by Haley \& Lee (1990) were from the same source, the higher ovulation rates observed may be characteristic of the Edinburgh Meishan population.

The unexpectedly poor survival of transferred Meishan embryos prevents distinction between conceptus and maternal contributions to prolificacy. However, there was no evidence of a maternal effect on embryo survival of control or Meishan embryos. 
The results from this experiment suggest that both fetal and maternal factors influence the growth and development of the feto-placental unit. Values of the three measures of fetal growth were lowest in the group in which Meishan embryos were transferred to Meishan recipients, highest in the control within-breed transfer group and intermediate in the across-breed transfer groups. This trend was still evident after differences in the number of fetuses occupying each horn were accounted for. These observations extend those of Bazer et al. (1988b) who found that, after natural mating, Large White fetuses had larger allantoic sacs on Day 30 than did Meishan fetuses, although Meishan and Large White fetuses were of comparable length and weight. The reason for this discrepancy is not clear, although it cannot be explained by the different number of fetuses per gilt on Day 30 in the two studies.

Embryos transferred to control recipient gilts developed into longer and heavier fetuses occupying larger allantoic sacs than embryos transferred to Meishan recipients. Bazer et al. (1988b) observed that on Day 30 Meishan gilts had shorter uteri than Large White gilts. The results from the current study are consistent with the concept that fetuses grow to occupy the space available to them, and with reports of a strong correlation between fetal weight and availability of uterine space (Rathnasabapathy et al., 1956). Similarly, fetuses in unilaterally hysterectomized-ovariectomized gilts were shorter, lighter and contained within smaller allantoic sacs than fetuses in intact control gilts (Knight et al., 1977), although in general these differences did not approach significance until Day 35 of pregnancy. Embryos from control donors developed into fetuses which were longer and occupied larger allantoic sacs than Meishan embryos. Examination of the predicted means of the three measures of conceptus growth reveals that maternal and fetal effects contribute approximately equally to the total breed differences in allantoic fluid volume and fetal length, whereas the maternal contribution to fetal weight is approximately $2 \cdot 5$-fold that of the (non-significant) fetal effect. Similarly crossbreeding trials between Meishan and Large White pigs have revealed that maternal genetic effects explain virtually all of the breed difference in piglet birth weight (D'Agaro et al., 1990). In this way Meishan mothers may be able to limit fetal growth, and therefore carry larger numbers of fetuses to term.

We thank Mr A. Simpson and Mr R. Simpson for excellent stockmanship; Dr D. A. H. Farningham for surgical procedures; and Mr C. Whyte and Mr C. Simpson for anaesthesia. Regumate was a generous gift from Hoechst UK.

\section{References}

Ashworth, C.J., Haley, C.S., Aitken, R.P. \& Wilmut, I. (1989) Reciprocal embryo transfers between Meishan and Large White gilts. J. Reprod. Fert., Abstract Series 4, 34.

Baker, R.J. \& Nelder, J.A. (1978) The Glim System. Release 3. Numerical Algorithms Group, Oxford, UK.

Bazer, F.W., Thatcher, W.W., Martinat-Botte, F. \& Terqui, M. (1988a) Sexual maturation and morphological development of the reproductive tract in Large White and prolific Chinese Meishan pigs. $J$. Reprod. Fert. 83, 723-728.

Bazer, F.W., Thatcher, W.W., Martinat-Botte, F. \& Terqui, M. (1988b) Conceptus development in Large White and prolific Chinese Meishan pigs. J. Reprod. Fert. 84, 37-42.

Bolet, G., Martinat-Botte, F., Locatelli, P., Gruano, J., Terqui, M. \& Berthelot, F. (1986) Components of prolificacy of hyperprolific Large White sows. Comparison with Meishan and control Large White sows. Genet. Sel. Evol. 18, 333-342.
Bidanel, J.P. \& Legault, C. (1986) Experimental and prospective aspects of the utilisation of prolific Chinese pig breeds in Europe. Proc. 37 th Meeting EAAP, Budapest, vol. 1, pp. 104-105, abstr.

D'Argaro, E., Haley, C.S. \& Ellis, M. (1990) Breed and genetic effects for pre and post-weaning performance in Large White and Meishan pigs and their crosses. Proc. 4th Wld Congr. Genetics Applied to Livestock Production Edinburgh, vol. XV, pp. 485-488.

Davis, D.L. (1985) Culture and storage of pig embryos. $J$. Reprod. Fert., Suppl. 33, 115-124.

Ellendorff, F., Martinat-Botte, F., Signoret, J.P. \& Terqui, M. (1988) Duration of oestrus and pre-ovulatory LH in the high fertility Meishan pig. Proc. 1lth Int. Congr. Anim. Reprod. \& AI, Dublin 2, 24.

Genstat 5 Committee (1989) Genstat 5 Reference Manual, Clavendon Press, Oxford, UK.

Haley, C.S. \& Lee, G.J. (1990) Genetic components of litter size in Meishan and Large White pigs and their crosses. Proc. 4th Wld Congr. Genetics Applied to Livestock Production, Edinburgh, vol. XV, 458-461. 
Haley, C.S., Ashworth, C.J., Lee, G.J., Wilmut, I., Aitken, R.P. \& Ritchie, W. (1990) British studies on the genetics of prolificacy in the Meishan pig. Proc. EA AP Chinese Pig Symposium, Toulouse, pp. 83-97.

Knight, J.W., Bazer, F.W., Thatcher, W.W., Franke, D.E. \& Wallace, H.D. (1977) Conceptus development in intact and unilaterally hysterectomized-ovariectomized gilts: interrelations among hormonal status, placental development, fetal fluids and fetal growth. J. Anim. Sci. 44, 620-637.

Meyen, B.A., Rosenkrans, C.F. \& Davis, D.L. (1989) Development of pig blastocysts in vitro is altered by serum, bovine serum albumin and amino acids and vitamins. Theriogenology 31, 463-471.

Polge, C. (1982) Embryo transplantation and preservation. In Control of Pig Reproduction, pp. 277-291. Eds D. J. A. Cole \& G. R. Foxcroft. Butterworth Scientific, London.

Pope, W.F., Lawyer, M.S., Nara, B.S. \& First, N.L. (1986) Effect of asynchronous superinduction on embryo survival and range of blastocyst development in swine. Biol. Reprod. 35, 133-137.
Rathnasabapathy, V., Lasley, J.F. \& Mayer, D.T. (1956) Genetic and environmental factors affecting litter size in swine. Bull. Mo. Agric. Exp. Stn 615.

Snedecor, G.W. \& Cochran, W.G. (1967) Statistical Methods, pp. 327-329. Iowa State University Press, Ames.

Varley, M.A., English, P.R., Davidson, F.M., MacPherson, O. \& Pawley, P. (1989) Control of oestrus and ovulation in peri-pubertal gilts with allyltrenbolone or a combination of natural gonadotrophins. Vet. Rec. 124, 186-189.

Wilmut, I., Haley, C.S., Ashworth, C.J., Aitken, R.P. \& Ritchie, W. (1990) Embryo development and embryo transfer in Meishan and Large White pigs. Proc. 4th Wld Congr. Genetics Applied to Livestock Production, Edinburgh, vol. XVI, pp. 347-350.

Yun, W.L. (1988) Pig breeds in China. Pig News and Information 9, 407-413.

Received 10 April 1990 